\title{
BEHAVIOUR OF NANOMATERIALS IN THE ENVIRONMENT: A STUDY OF INTERACTION BETWEEN HUMIC ACIDS AND FULLERENE $\mathbf{C}_{60}$
}

\author{
M. Klavins ${ }^{1}$, L. Ansone ${ }^{1}$, A. Zicmanis ${ }^{2}$ \\ ${ }^{1}$ Department of Environmental Science, University of Latvia, Raina blvd. 19, Riga, LV 1586, \\ Latvia; e-mail: maris.klavins@lu.lv \\ ${ }^{2}$ Faculty of Chemistry, University of Latvia, 19 Raina Blvd., LV 1586, Riga, Latvia
}

Interaction between buckminsterfullerene and humic substances of different origin was investigated using fluorescence spectrometry as function of concentration of humic substances, $\mathrm{pH}$ and ionic strength. Binding constants of humic substances and buckminsterfullerene were calculated. It can be suggested that the complexation was driven by hydrophobic interaction depending on properties of the interacting compounds. Hydrophobic interaction model was indicated by linear Stern-Volmer plot, and high $K_{d}$ values characterized interaction between buckminsterfullerene and humic acids. The results of this study support the development of understanding of fate of nanomaterials in environment as well as development of analytical techniques for nanomaterials in water and wastewater treatment approaches.

Key words: humic acid, fullerene $C_{60}$, binding, fluorescence spectroscopy.

\section{INTRODUCTION}

The growth of nanotechnology applications requires the environmental impact assessment of elaborated nanomaterials to reduce the environmental risks in case of their releases and possible pollution. Buckminsterfullerene $\mathrm{C}_{60}$ is an example of carbon-containing nanomaterials with diversity of potential applications [1, 2], environmental and health effects being possible also [3, 4]. The poor solubility of $\mathrm{C}_{60}$ in natural waters is a major factor controlling the environmental transport and biological interactions. However, in several studies toxic impacts on living organisms have been found related to necrotic and apoptic cellular damage, impacts on fish embryos [5]; other types of the toxic action might be identified also [6]. The first phase of the action on living organisms in the aquatic environment could be the interaction of nanoparticles, carbon nanomaterials and also $\mathrm{C}_{60}$ with natural organic matter-humic substances $[7,8]$.

Humic substances present in surface waters have a key role in terrestrial and aquatic biogeochemistry [9]. Humic substances (HS) are the most widely found naturally occurring organic substances [10]. Humic substances are general category of naturally occurring, biogenic, heterogeneous organic substances that can generally be characterized as being yellow to black in colour, of high molecular weight and refractory. Humic substances can be divided in three fractions: a) humin - the fraction of humic substances that is not soluble in water at any $\mathrm{pH}$; b) humic acid (HA) - the fraction of humic substances that is not soluble in water under acidic conditions (below $\mathrm{pH}$ 2), but becomes soluble 
at greater $\mathrm{pH}$; c) fulvic acid - the fraction of humic substances that is soluble under all $\mathrm{pH}$ conditions [10]. Humic substances influence the mineral weathering, the nutrient cycling, the aggregation and photochemical reactions in waters, and they serve as substrate for bacterial growth in the hydroecosystems, control light absorption [11-14].

The interaction of humic substances with xenobiotics may modify the uptake and toxicity of these compounds, and affect the fate of pollutants in the environment $[15,16]$.

The aquatic humic substances are found to be able to solubilize fullerene $\mathrm{C}_{60}$ and their apparent solubility in water in the presence of HAs can be $\sim 500$ times higher than the solubility in pure water. A significant stage in the solubilization process is the adsorption of $\mathrm{C}_{60}$ on humic substances, and this process might influence the behaviour of nanoparticles in the environment [17].

To study the interaction between humic substances and buckminsterfullerenes high performance liquid chromatography on a humic acid stationary phase has been suggested [18], but also dynamic light scattering has been used [19]. However, as a tool to study complexing with humic substances, a fluorescence spectroscopic method (fluorescence quenching due to the complex formation) has found widespread application [16, 20]. This method has an advantage in that it is a simple, quick and reliable method avoiding the complicated separation of the complex from individual substances [21].

The aim of the present study is to analyze the complexing between humic substances and fullerene $\mathrm{C}_{60}$, as well as to study the impact of environmental factors and properties of humic substances on the complex formation.

\section{EXPERIMENTAL}

Analytical quality reagents were used without further purification. All chemicals used in this study were of analytical quality. For the preparation of solutions, high purity water Millipore Elix 3 (Millipore Co.) $10-15 \mathrm{M} \Omega / \mathrm{cm}$ was used throughout. Fullerene was purchased from TCI Europe (Belgium).

Humic acids from Gagu bog (Latvia) peat were extracted and purified using procedures recommended by the International Humic Substance Society (IHSS) [22]. Humic acids from waters of the River Daugava (Latvia) were obtained as suggested by Thurman and Malcolm [23]. Reference humic acids were purchased from Sigma-Aldrich Co (Aldrich HA) and the International Humic Substances Society (Leonardite HA). The properties of the studied humic substances are reported in Table 1.

Fullerene solutions were made as previously described [24] in dimethyl sulfoxide because of its poor solubility in water. Fullerene stock solution concentration was $10 \mathrm{mg} / \mathrm{l}$. Solution of Aldrich HA was prepared by dissolving necessary amount of HA in water, however Leonardite, Gagu and Daugava HA were dissolved in $0.1 M \mathrm{NaOH}$ solution and then diluted to the necessary concentration. Aliquots of the stock solutions of HS and fullerene were mixed in proportion 1:1. Final concentration of HA was $5 \mathrm{mg} / \mathrm{l}$, but final concentrations of fullerene were $5,4,3,2,1,0.5$ and $0.1 \mathrm{mg} / \mathrm{l}$. Solution of HS and fullerene were poured into a quartz cell. The fluorescence spectra were obtained on a spectrofluorometer Perkin Elmer LS55 at room temperature $\left(25^{\circ} \mathrm{C}\right)$. The fluorescence emission spectra results were recorded at speed of $500 \mathrm{~nm} / \mathrm{min}$, at excitation of $350 \mathrm{~nm}, 8 \mathrm{~nm}$ (Ex) and $8 \mathrm{~nm}$ (Em) slit widths. 
Table 1. Composition and characteristics of humic acids used in this study

\begin{tabular}{c|c|c|c|c}
\hline Characteristics & $\begin{array}{c}\text { Aldrich } \\
\text { HA }\end{array}$ & $\begin{array}{c}\text { Leonardite } \\
\text { HA }\end{array}$ & $\begin{array}{c}\text { Daugava } \\
\text { HA }\end{array}$ & $\begin{array}{c}\text { Gagu bog } \\
\text { HA }\end{array}$ \\
\hline Elemental analysis data, \% & \multicolumn{4}{|l}{} \\
C & 60.70 & 63.81 & 51.42 & 54.32 \\
$\mathrm{H}$ & 3.70 & 3.70 & 4.48 & 5.03 \\
$\mathrm{~N}$ & 1.50 & 1.23 & 0.97 & 2.36 \\
$\mathrm{O}$ & 34.10 & 31.27 & 40.21 & 36.78 \\
Functional analysis data: & & & & \\
COOH, mEq/g & 2.15 & 3.16 & 4.34 & 4.15 \\
Total acidity, mEq/g & 3.32 & 5.77 & 5.39 & 5.63 \\
O/C & 0.65 & 0.37 & 0.59 & 0.51 \\
$\mathrm{H} / \mathrm{C}$ & 1.13 & 0.69 & 1.04 & 1.10 \\
$E_{4} / E_{6}$ & 4.51 & 3.65 & 8.97 & 5.84
\end{tabular}

Influence of pH on HA-fullerene interaction. Aldrich HA were dissolved in water, and Leonardite $\mathrm{HA}$ were dissolved in $0.1 \mathrm{~N} \mathrm{NaOH}$ (final concentration of HA was $5 \mathrm{mg} / \mathrm{l}$ ) and mixed with the stock solution of fullerene to reach final concentration of fullerene $(5 \mathrm{mg} / \mathrm{l})$. $\mathrm{pH}$ values were adjusted from $\mathrm{pH} 3.09$ to pH 8.98 with $0.1 \mathrm{~N} \mathrm{HCl}$ and $0.1 \mathrm{~N} \mathrm{NaOH}$. Conditions for fluorescence analyses were as previously mentioned.

Influence of ionic strength on HA-fullerene interactions. Binding sites of HS were investigated using solutions of $\mathrm{HA}$, fullerene and $\mathrm{NaNO}_{3}$ so that the concentrations of $\mathrm{NaNO}_{3}$ were $1 \mathrm{~mol} / 1,0.75 \mathrm{~mol} / 1,0.5 \mathrm{~mol} / 1,0.25 \mathrm{~mol} / 1$, $0.1 \mathrm{~mol} / 1$ and $0.05 \mathrm{~mol} / \mathrm{l}$, while the final concentration of $\mathrm{HA}$ was $5 \mathrm{mg} / \mathrm{l}$ and that of fullerene was also $5 \mathrm{mg} / \mathrm{l}$. Solutions were well mixed and fluorescence emission spectra were then recorded.

\section{RESULTS AND DISCUSSION}

The synchronous-scan fluorescence excitation emission spectra (SSFS) of humic substances are shown in Figure 1, and they differ significantly depending on the origin of humic acids: spectra of highly humified HAs (IHSS reference humic acids: Leonardite HA, the industrially produced Aldrich HA, peat HA and aquatic HA) are characterized by two major fluorescence peaks. Aquatic humic acids isolated from water of the River Daugava are characterized by one peak (maximum at $\sim 375 \mathrm{~nm}$ ), but peat humic acids (isolated from Gagu sphagnum bog peat) are characterized by two peaks (maxima at $~ 345$ and $375 \mathrm{~nm}$ ). Synchronous-scan spectra of humic substances isolated from highly humified organic material (leonardite, coal) have an intensive fluorescence peak at $\sim 475 \mathrm{~nm}$ that can be assigned to the presence of conjugated unsaturated bond systems bearing carbonyl and carboxyl groups (substituting aromatic core structures), but its intensity differs with respect to aromaticity of humic acid selected [25].

The fluorescence emission spectra of studied humic acids are shown in Figure 2. However, in comparison with SSFS the emission spectra do not show great differences - their main differences lay in their intensity and wavelengths of location of fluorescence maxima of each humic substance. This may be assigned to the different modifications of the fluorophoric structures in humic molecules. 


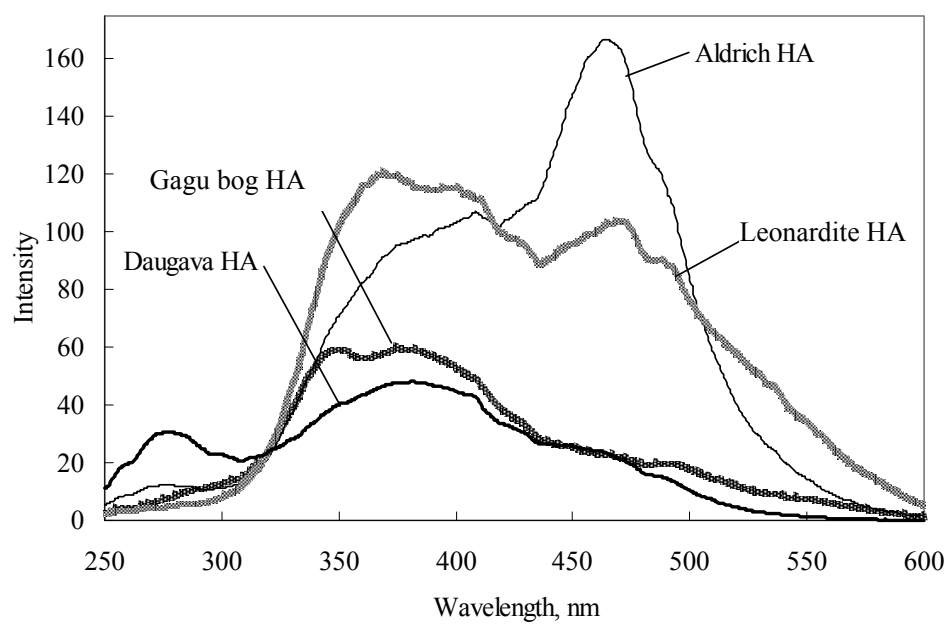

Fig. 1. Fluorescence synchronous spectra of studied humic acids $\left(C_{\mathrm{HA}}=25 \mathrm{mg} / \mathrm{l}, \mathrm{pH} 7\right)$.

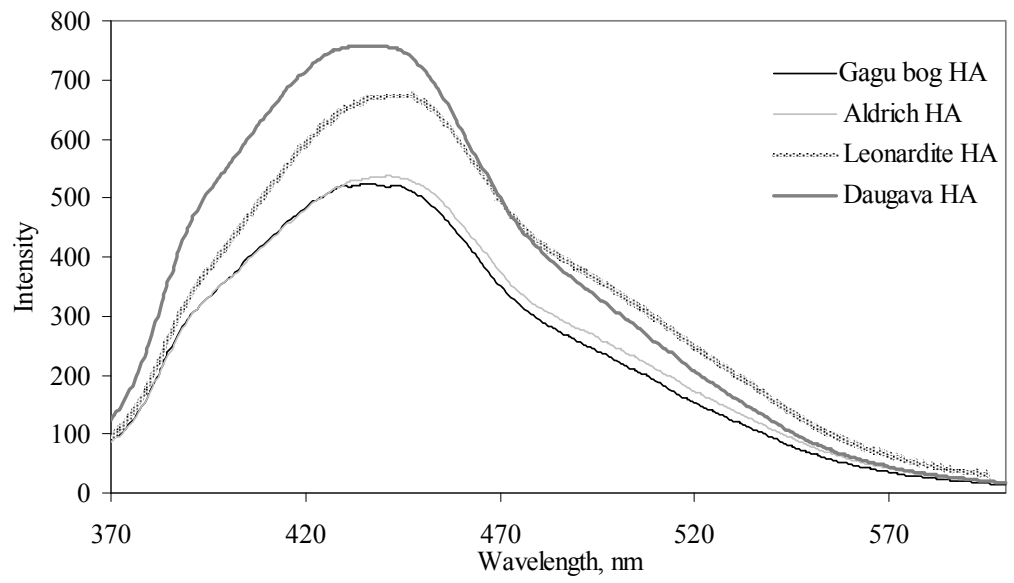

Fig. 2. Fluorescence emission spectra of studied humic acids $\left(C_{\mathrm{HA}}=5 \mathrm{mg} / \mathrm{l}\right.$, excitation at $\left.350 \mathrm{~nm}\right)$.

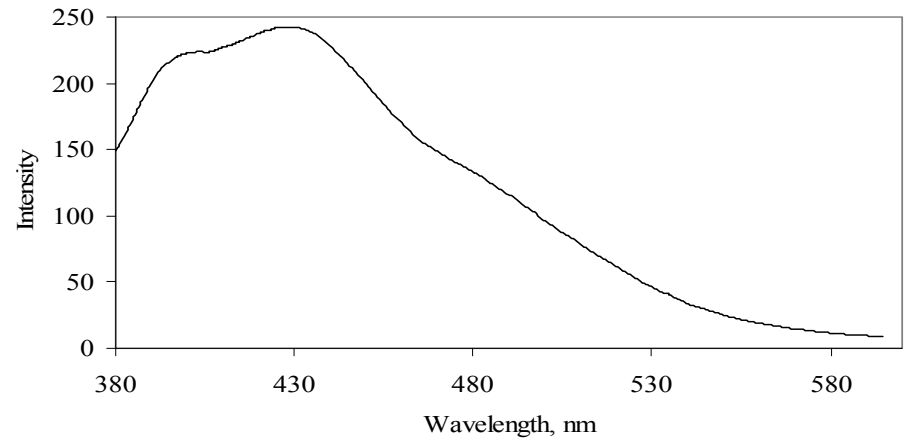

Fig. 3. Fluorescence emission spectra of fullerene $\mathrm{C}_{60}$ $\left(C_{\mathrm{C}_{60}}=5 \mathrm{mg} / \mathrm{l}\right.$, excitation at $\left.350 \mathrm{~nm}\right)$.

Fluorescence emission spectrum of fullerene $\mathrm{C}_{60}$ (Fig. 3) is similar to that of humic substances, but the comparative intensity of fullerene emission spectra is lower and also fluorescence maxima peaks are slightly shifted towards the shorter wavelengths. 


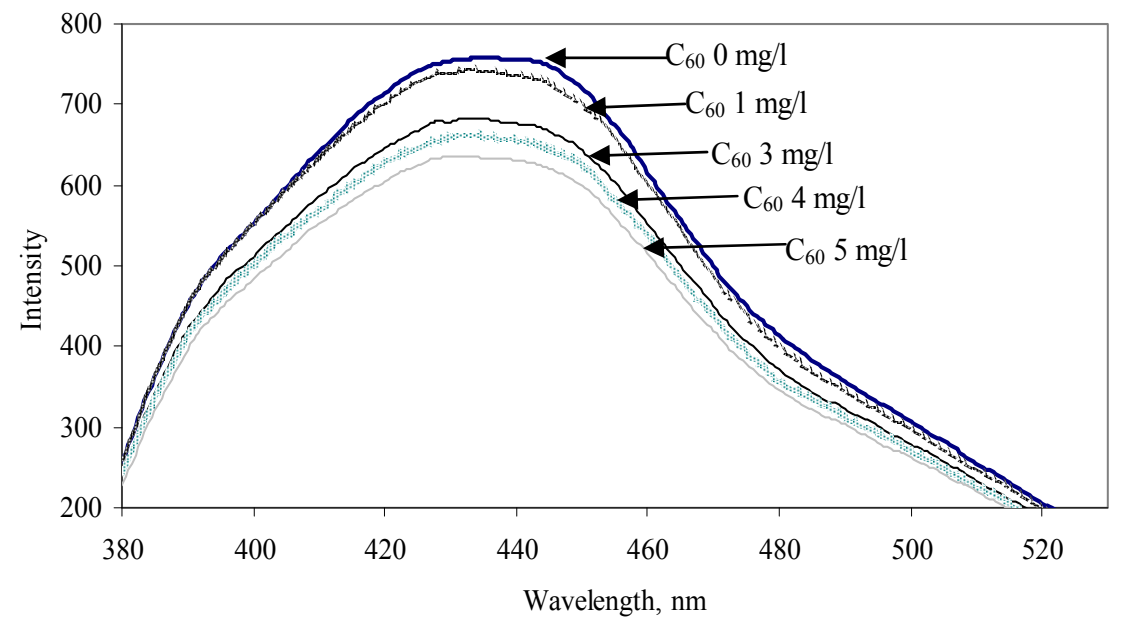

Fig. 4. Fluorescence emission spectra of Daugava HA in the absence and the presence of fullerene $\left(C_{\mathrm{HA}}=5 \mathrm{mg} / \mathrm{l}\right)$.

The fluorescence emission spectra of the studied humic acids in the presence and absence of fullerene have demonstrated the quenching of the fluorescence peak at $\sim 440 \mathrm{~nm}$, associated with the presence of aromatic structures in humic molecules (Fig. 4). Thus, the fluorescence quenching methodology in our study differs from the approach used when studying binding between humic substances and polyaromatic hydrocarbons [15]. As far as this case is concerned, the fluorophore structures in the humic acid molecules are quenched, and fullerene is the quencher. In this respect, the interaction between humic acids is similar to that with metal ions [26] and Carbamazepine [20], and such an approach supports the analysis of interaction between humic substances and a large number of substances of interest. The fluorescence intensities of peaks at $440 \mathrm{~nm}$ have exhibited a successive decrease as the concentrations of fullerene increased (Fig. 4).

The intensity of the fluorescence quenching is supposed to be proportional to the concentration of the formed humic substance - complex of substance of interest according to the Stern-Volmer equation [27]. The fluorescence of humic acid quenching mechanism by fullerene is considered in the 1:1 interaction model.

The binding constants are obtained by steady-state fluorescence quenching measurements and are given as a slope in the Stern-Volmer plot. The interaction between humic substances and fullerene $\left(\mathrm{C}_{60}\right)$ can be described as follows:

$$
\mathrm{C}_{60}+\mathrm{HA} \leftrightarrow \mathrm{C}_{60}-\mathrm{HA}
$$

with the corresponding binding constant $K_{\mathrm{b}}$ :

$$
K_{\mathrm{b}}=\frac{\left[\mathrm{C}_{60}-\mathrm{HA}\right]}{\left[\mathrm{C}_{60}\right][\mathrm{HA}]} .
$$

The total concentration of humic acid $\mathrm{HA}_{\mathrm{t}}$ can be expressed as a sum of free humic acids $\mathrm{HA}_{\mathrm{f}}$ and bound humic acids, $\mathrm{HA}_{\mathrm{b}}$ :

$$
\mathrm{HA}_{\mathrm{t}}=\mathrm{HA}_{\mathrm{f}}+\mathrm{HA}_{\mathrm{b}} \text {. }
$$


Introducing Eq (2) into Eq (3) we obtain:

$$
\begin{gathered}
\mathrm{HA}_{\mathrm{t}}=\mathrm{HA}_{\mathrm{f}}+\mathrm{HA}_{\mathrm{f}} K_{\mathrm{b}}\left[\mathrm{C}_{60}\right] ; \\
\frac{\mathrm{HA}_{\mathrm{t}}}{\mathrm{HA}_{\mathrm{f}}}=1+K_{\mathrm{b}}\left[\mathrm{C}_{60}\right] .
\end{gathered}
$$

As far as intensity ratio of fluorescence of the initial substance and fluorescence in the presence of quencher, $I_{0} / I$ is proportional to $\mathrm{HA}_{t} / \mathrm{HA}_{\mathrm{f}}$, Eq. (5) can be modified:

$$
\frac{I_{0}}{I}=1+K_{\mathrm{b}}\left[\mathrm{C}_{60}\right]
$$

However, for practical application the equilibrium concentration of fullerene $\left[\mathrm{C}_{60}\right]$ can be replaced by the total concentration $C_{\mathrm{C}_{60}}$ as the concentrations of $\mathrm{C}_{60}$ bound to humic substances under the experimental concentrations were much lower than the concentrations of the humic substances:

$$
\frac{I_{0}}{I}=1+K_{\mathrm{b}} C_{\mathrm{C}_{60}}
$$

The binding constant can be calculated:

$$
K_{\mathrm{b}}=\frac{\frac{I_{0}}{I}-1}{C_{\mathrm{C}_{60}}} .
$$

The character of the relationships from modified Stern-Volmer plots (Fig. 5) offer strong support for the 1:1 complex $\left(r^{2}>0.97\right)$.

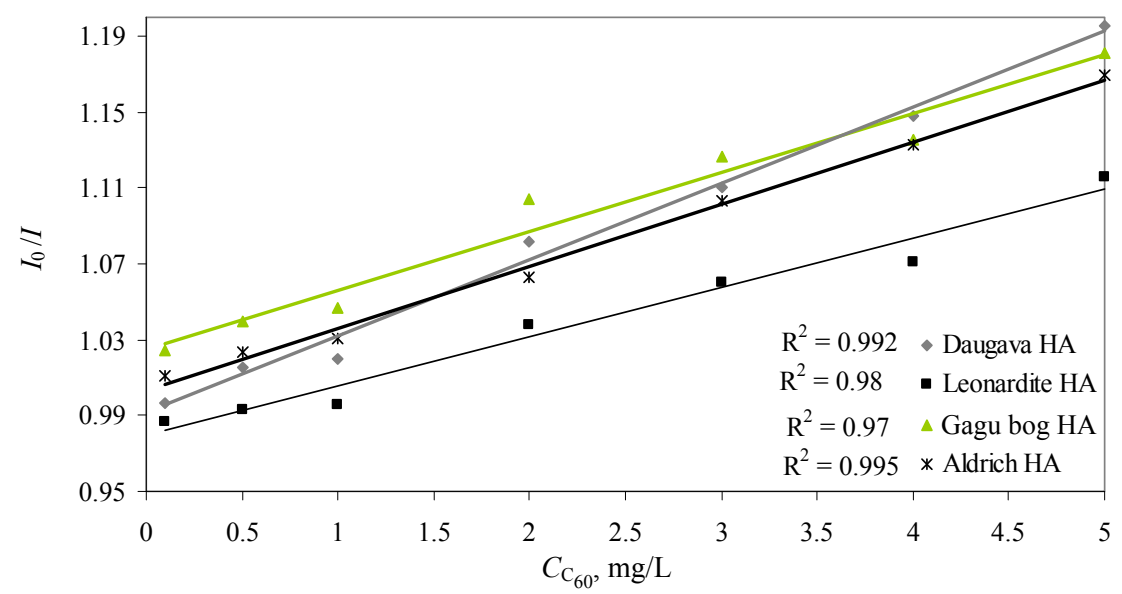

Fig. 5. Stern-Volmer plots: the ratio of $I_{0} / I$ of $\mathrm{HA}-\mathrm{C}_{60}$ as a function of $C_{\mathrm{C}_{60}}$ $\left(C_{\mathrm{HA}}=5 \mathrm{mg} / \mathrm{l}\right)$.

Quenching may occur by a plenty of mechanisms as either static or dynamic quenching. Dynamic quenching is a process in which the fluorophore and the quencher come into contact during the lifetime of the excited state and involves 
the energy transfer, while static quenching is a process where non-fluorescent complex of the ground state fluorophore is formed. For monodisperse systems, the fluorescence quenching data have a linear dependence when presented as a Stern-Volmer plot by plotting $I_{0} / I$ against concentration of quencher, and deviations from linearity carry information on the nature of the quenching process and fluorophore - quencher interaction [28]. If the linear Stern-Volmer plot indicates a single class of fluorophores with equal accessibility to the quencher, then a combination of the dynamic and static quenching typically produces nonlinear Stern-Volmer plots [29]. Therefore it is very important to explore the linearity of Stern-Volmer plots; it is an excellent tool to understand the organic matter interactions with fullerene nanoparticles. Fluorescence quenching of humic acid by fullerene can be described by linear Stern-Volmer plots (Fig. 5), therefore it is possible that there is only one quenching process, on the basis of HA-fullerene interaction. This quenching most likely involves one quenching mechanism - static or dynamic. In comparison to interaction of other nanoparticles (for example iron nanoparticles) with humic substances, Stern-Volmer plots are non-linear - indicating the occurrence of more than one quenching process [28], but interaction between humic substances and pyrene and its derivatives shows linear Stern-Volmer plots [16] as well as interaction between phenanthrene and humic substances, also suggesting that either static and dynamic fluorescence quenching mechanism dominates [30]. However, for interaction between fullerene $\left(\mathrm{C}_{60}\right)$ and cryptophanes $\mathrm{A}$ and $\mathrm{E}$, linear SternVolmer plots are characteristic, and similar to our study fluorescence of the studied substance is quenched by fullerene. It is suggested that fullerene may interact with natural organic matter due to the hydrophobic interaction model $[31,32]$.

The calculated $\log K_{\mathrm{b}}$, values for different humic acids and fullerene are shown in Figure 6.

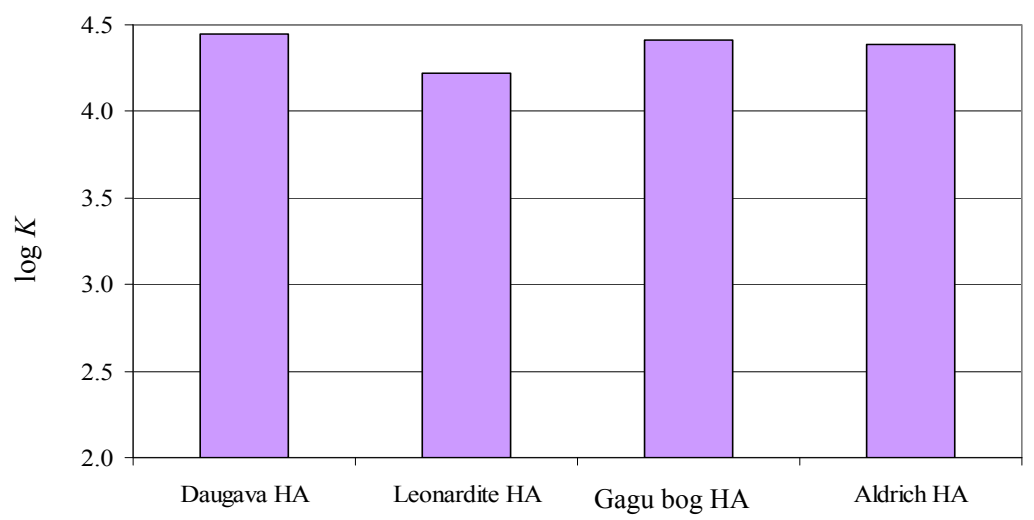

Fig. 6. Stern-Volmer constants $\left(K_{\mathrm{b}}, 1 / \mathrm{mol}\right)$ of binding between the studied humic substances $\left(C_{\mathrm{HA}}=5 \mathrm{mg} / \mathrm{l}\right)$ and fullerene $\left(C_{\mathrm{C}_{60}}=5 \mathrm{mg} / \mathrm{l}\right)$.

$\log K$ values fall in range from 4.11 to $5.25 \mathrm{l} / \mathrm{mol}$ for the studied humic substances and fullerene. The observed $\log K_{\mathrm{b}}$ values for the interaction between fullerene and studied humic acids are similar to the values found in previous study $\left(\log K_{\mathrm{b}}=3.85-4.82 \mathrm{l} / \mathrm{mol}\right)$ using soil humic acid and polycyclic aromatic compounds [15] and also interaction between fullerene and cryptophanes shows $\log K$ values from 4.93 to $5.931 / \mathrm{mol}$ [31]. Strong binding 
is found to occur in the case of the interaction between Gagu bog HA and fullerene. The lower $\log K$ value is characteristic of the interaction between fullerene $\left(C_{\mathrm{C}_{60}}=4 \mathrm{mg} / \mathrm{l}\right)$ and Leonardite $\mathrm{HA}\left(C_{\mathrm{HA}}=5 \mathrm{mg} / \mathrm{l}\right) \log K_{\mathrm{b}}=4.11$.

To understand the likely fate and behaviour of nanoparticles in environment, it is important to understand their interaction with natural environment components under a variety of physicochemical conditions, for example $\mathrm{pH}$, the type and concentration of natural organic macromolecules. It is suggested that the aggregate size increases with increasing the humic acid concentration and $\mathrm{pH}$. It could have one or more reasons, for example, increased aggregation of particles, increased humic acid adsorption, because of the increase of surface coating thickness, changing humic acid conformation, additional formation of nanoparticle layers on the existing particles by further hydrolysis with the increase in $\mathrm{pH}$ [8]. It also could be related to chemical changes on $\mathrm{pH}$ basis, leading to electronic changes in humic acid molecules, the full deprotonation of carboxylic and other functional groups leading to the charge repulsion and change in the conformation of the humic acid as $\mathrm{pH}$ increases [28]. The $\mathrm{pH}$ will affect dissociation of functional groups and develop differences in amount of negative charge on the humic substances. At lower $\mathrm{pH}$ values, there is less dissociation, at neutral $\mathrm{pH}$ humic substances reduce electrostatic forces by aligning the hydrophobic structures together in core and aligning the charged functional groups in the molecule towards the solvating of water molecules. On higher $\mathrm{pH}$, there will be more dissociation but it will be energetically more favourable for the hydrophobic groups to align on the surface [33].

Obviously, in Figure 7 fluorescence quenching at a constant concentration of nanoparticles and constant humic acid concentration is highly $\mathrm{pH}$ dependent. It could be suggested that humic- $\mathrm{C}_{60}$ interaction is influenced by the conformation changes of humic substances.

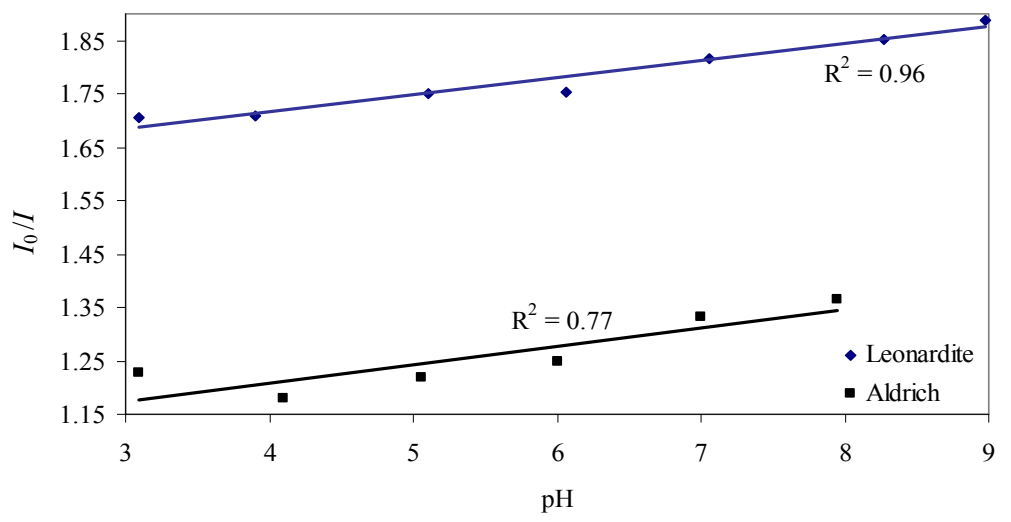

Fig. 7. Influence of $\mathrm{pH}$ on fluorescence quenching of humic acids by fullerene $\left(C_{\mathrm{HA}}=5 \mathrm{mg} / \mathrm{l}, C_{\mathrm{C}_{60}}=5 \mathrm{mg} / \mathrm{l}\right)$.

Figure 8 shows that with increase of the ionic strength the fluorescence intensity of $\mathrm{HA}-\mathrm{C}_{60}$ complex significantly decreases. As mentioned earlier, $\mathrm{pH}$ affects the particle size, and also the ionic strength can alter the size of particles and alter the stability of the formed complexes as it is found in the case of humic - polyaromatics interaction [33]. This may indicate the preferential binding of highly hydrophobic fullerene $\left(\mathrm{C}_{60}\right)$ to more hydrophobic structures, with consecutive changes in the conformation of humic macromolecules. 


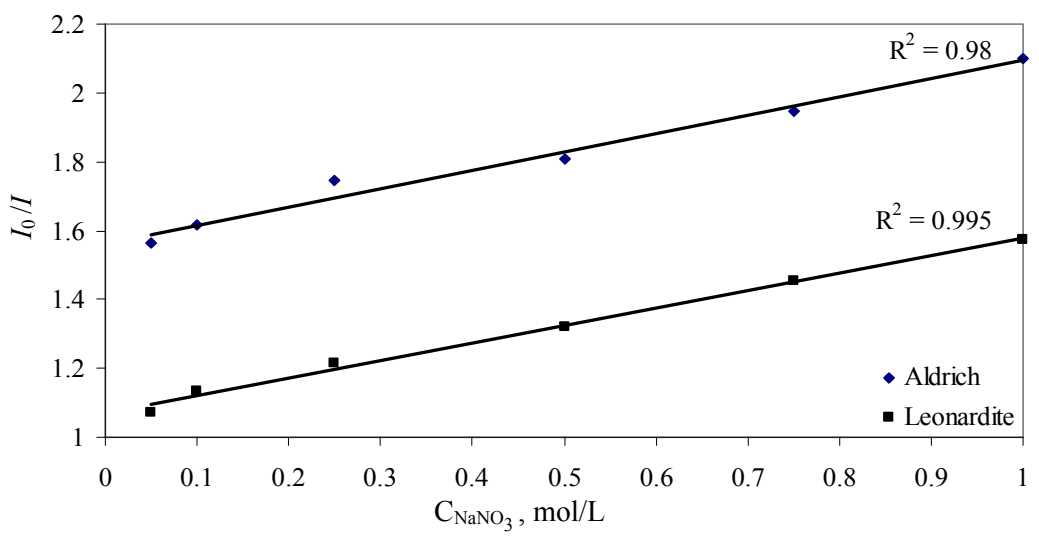

Fig. 8. Influence of ionic strength on fluorescence quenching by fullerene

$$
\left(C_{\mathrm{HA}}=5 \mathrm{mg} / \mathrm{l}, C_{\mathrm{C}_{60}}=5 \mathrm{mg} / \mathrm{l}\right) \text {. }
$$

\section{CONCLUSIONS}

Buckminsterfullerene $\mathrm{C}_{60}$ causes quenching of the fluorescence signal of humic substances and the intensity of the quenching is proportional to the concentration of $\mathrm{C}_{60}$. Thus the ratio $I_{0} / I$ can be used to estimate the complexing process as known in metal-humic acid interaction studies.

We have determined the binding constants between fullerene and studied humic acids, using the fluorescence quenching technique. The obtained values are similar to those between humic substances and polycyclic aromatic hydrocarbons determined in other studies. Our findings suggest that hydrophobic interactions play dominant role in the complex formation between humic acids and fullerene $\mathrm{C}_{60}$. The importance of the hydrophobic attraction between humic acids and fullerene $\mathrm{C}_{60}$ is also confirmed by salt effect and $\mathrm{pH}$ dependence of the fluorescence quenching effect. The hydrophobic interaction between fullerene $\mathrm{C}_{60}$ and $\mathrm{HA}$ is weakened at low $\mathrm{pH}$, resulting in a decrease in the binding constants. The results of this study support the development of understanding of the fate of nanomaterials in the environment as well as the development of analytical methods for nanomaterial determination in waters and wastewater treatment approaches.

\section{REFERENCES}

1. Bogdanov, A.A., Deininger, D., Dyuzhev, G.A. (2000). Development prospects of the commercial production of fullerenes. Techn. Physics. 45, 521-527.

2. Masciangioli, T., Zhang, W.X. (2003). Environmental technologies at the nanoscale. Environ. Sci. Technol. 37, 102A-108A.

3. Klaine, S.J., Alvarez, P.J.J., Batley, G.E., Fernandes, T.F., Handy, R.D., Lyon, D.Y., Mahendra, S., McLaughlin, M.J., Lead, J.R. (2008). Nanomaterials in the environment: behaviour, fate, bioavailability and effects. Environ. Toxicol. Chem. 27 (9), 1825-1851.

4. Velzeboer, I., Hendriks, A.J., Ragas, A.M.J., Meent, D. (2008). Aquatic ecotoxicity tests of some nanomaterials. Environ. Toxicol. Chem. 27 (9), 1942-1947.

5. Usenko, C.Y., Harper, S.L., Tanguay, R.L. (2007). In vivo evaluation of carbon fullerene toxicity using embryonic zebrafish. Carbon. 45, 1891-1898.

6. Oberdorster, G., Oberdorster, E., Oberdorster, J. (2005). Nanotoxicology: an emerging discipline evolving from studies of ultrafine particles. Environ. Health Perspectives. 113 (7), 823-839.

7. Illes, E., Tombacz, E.J. (2006). The effect of humic acid adsorption on pH-dependent surface charging and aggregation of magnetite nanoparticles. Coll. Interface Sci. 295, 115-123. 
8. Baalousha, M., Manciulea, A., Comberland, S., Kendall, K., Lead, J.R. (2008). Aggregation and surface properties of iron oxide nanoparticles: influence of $\mathrm{pH}$ and natural organic matter. Environ. Toxicol. Chem. 27 (9), 1875-1882.

9. Neff, J.C., Asner, G.P. (2001). Dissolved organic carbon in terrestrial ecosystems: synthesis and a model. Ecosystems. 4 (1), 29-48.

10. Stevenson, F.J. (1994). Humus chemistry: Genesis, composition, reactions. 2nd ed. New York, Wiley.

11. Depetris, P.J., Kempe, S. (1993). Carbon dynamics and sources in the Parana River. Limnol. Oceanogr., 38 (2), 382-395.

12. Pettine, M., Patrolecco, L., Camusso, M., Crescenzio, S. (1998). Transport of carbon and nitrogen to the Northern Adriatic Sea by the Po River. Estuarine, Coastal Shelf Sci. 46, 127142.

13. Wasterhoff, P., Anning, D.J. (2000). Concentrations and characteristics of organic carbon in surface water in Arizona: influence of urbanization. Hydrol. 236, 202-222.

14. Evans, C.D., Monteith, D.T., Cooper, D.M. (2005). Long-term increases in surface water dissolved organic carbon: observations, possible causes and environmental impacts. Environ. Pollut. 137, 55-71.

15. Karthikeyan, K.G., Chorover, J. (2002). Humic acid complexation of basic and neutral polycyclic aromatic compounds. Chemosphere. 48, 955-964.

16. Nakashima, K., Maki, M., Ishikawa, T., Yoshikawa, T., Gong, Y.-K. Miyajima, T. (2007). Fluorescence studies on binding of pyrene and its derivatives to humic acid. Spectrochim. Acta, Pt A. 67, 930-935.

17. Terashima, M., Nagao, S. (2007). Solubilization of [60] fullerene in water by aquatic humic substances. Chem. Lett. 36 (2), 302-303.

18. Casadei, N., Thomassin, M., Guillaume, Y.C., Andre, C. (2007). A humic acid stationary phase for high performance liquid chromatography separation of buckminsterfullerenes: theoretical and practical aspects. Anal. Chim. Acta. 588, 268-273.

19. Chen, K.L., Elimelech, M.J. (2007). Influence of humic acid on the aggregation kinetics of fullerene $\left(\mathrm{C}_{60}\right)$ nanoparticles in monovalent and divalent electrolyte solutions. Coll. Interface Sci. 309, 126-134.

20. Bai, Y., Wu, F., Liu, C., Guo, C., Fu, P., Li, W., Xing, B. (2008). Interaction between carbamazepine and humic substances: a fluorescence spectroscopy study. Environ. Toxicol. Chem. 27 (1), 95-102.

21. Peuravuori, J. (2001). Partition coefficients of pyrene to lake aquatic humic matter determined by fluorescence quenching and solubility enhancement. Anal. Chim. Acta. 429 (1), 65-73.

22. Tan, K.H. (2005). Soil Sampling, Preparation, and Analysis. $2^{\text {nd }}$ ed. New York, Taylor and Francis.

23. Thurman, E.M., Malcolm, R.L. (1981). Preparative isolation of aquatic humic substances. Environ. Sci. Technol. 15, 463-466.

24. Chen, Z., Westerhoff, P., Herckes, P. (2008). Quantification of $\mathrm{C}_{60}$ fullerene concentrations in water. Environ. Toxicol. Chem. 27 (9), 1852-1859.

25. Peuravuori, J., Koivikko, R., Pihlaja, K. (2002). Characterization, differentiation and classification of aquatic humic matter separated with different sorbents: synchronous scanning fluorescence spectroscopy. Water Res. 36, 4552-4562.

26. Alberts, J.J., Takacs, M. (2004). Total luminescence spectra of IHSS standard and reference fulvic acids, humic acids and natural organic matter: comparison of aquatic and terrestrial source terms. Org. Geochem. 35, 243-256.

27. Gauthier, T.D., Shane, E.C., Guerlayn, W.F., Seilz, W.R., Grant, C.L. (1986). Fluorescence quenching method for determining equilibrium constants for polycyclic aromatic hydrocarbons binding to dissolved humic materials. Environ. Sci. Technol. 20, 1162-1166.

28. Manciulea, A., Baker, A., Lead, J.R. (2009). A fluorescence quenching study of the interaction of Suwannee river fulvic acid with iron oxide nanoparticles. Chemosphere. 76, $1023-1027$.

29. Gadad, P., Lei, H., Nanny, M.A. (2007). Characterization of noncovalent interactions between 6-propionyl-dimethylaminonapthalene (PRODAN) and dissolved fulvic and humic acids. Water. Res. 41, 4488-4496.

30. Lee, C.L., Kuo, L.J., Wang, H.L., Hsieh, P.C. (2003). Effects of ionic strength on the binding of phenanthrene and pyrene to humic substances: three stage variation model. Water Res. $37,4250-4258$. 
31. Zhang, C., Shen, W., Fan, R., Zhang, G., Shangguan, L., Chao, J., Shuang, S., Dong, C., Choi, M.M.F. (2009). Study of the contact charge transfer behavior between cryptophanes (A and E) and fullerene by absorption, fluorescence and ${ }^{1} \mathrm{H}$ NMR spectroscopy. Anal. Chim. Acta. 650, 118-123.

32. Isaacson, C.W., Kleber, M., Field, J.A. (2009). Quantitative Analysis of Fullerene Nanomaterials in Environmental Systems: A Critical Review. Environ. Sci. Technol. 43 (17), $6463-6474$.

33. Wilson, M.A., Tran, N.H., Milev, A.S., Kannangara, G.S.K., Volk, H., Lu, M.G. (2008). Nanomaterials in soils. Geoderma. 146, 291-302.

\section{Kḷaviņš, L. Ansone, A. Zicmanis}

NANOMATERIĀLI VIDĒ: MIJIEDARBĪBAS IZPĒTE STARP HUMUSVIELĀM UN FULLERĒNU $\mathrm{C}_{60}$

\section{K O P S A V I L K U M S}

Mijiedarbība starp bukminsterfullerēnu un dažādas izcelsmes humusvielām pētīta, izmantojot fluorescences spektrometriju, atkarībā no humusvielu koncentrācijas, šķīduma $\mathrm{pH}$ un jonu spēka. Aprēķinātas fullerēna - humusvielu kompleksveidošanās konstantes. Domājams, ka reakcijas pamatā ir hidrofoba mijiedarbība, ko nosaka reaǵējošo vielu īpašības. Šterna-Volmera grafika linearitāte norāda uz hidrofobo mijiedarbību, un augstās $K_{\mathrm{d}}$ vērtības raksturo mijiedarbību starp bukminsterfullerēnu $C_{60}$ un humīnskābēm. Ši pētījuma rezultāti var tikt izmantoti, lai izprastu nanomateriālu izturēšanos vidē, kā arī nanomateriālu pētījumu analītisko metožu attīstībai ūdens un notekūdeņu attīì̄̌sanas procesiem. 